\title{
EXPOSING POLICE CORRUPTION AND MALFEASANCE: CHINA'S VIRGIN PROSTITUTE CASES
}

\section{Elaine Jeffreys*}

This paper examines prostitution-related police corruption and malfeasance in the People's Republic of China (PRC) during the early 2000s, as exemplified by media coverage of the story of Ma Dandan and six other "virgin prostitute cases" (chunü maiyin an 处女卖淫案). At 8 p.m. on 8 January 2001, Ma Dandan, an eighteen-year-old woman from Jingyang County in Shaanxi Province, was watching television with her brother-in-law and niece in her sister's hairdressing salon. Two plainclothes police officers, Wang Haitao and Hu Anding, entered the premises and took her to the local police station for questioning about alleged involvement in the banned practice of prostitution. At the station, Wang and $\mathrm{Hu}$, in the presence of chief police officer, Peng Liang, subjected Ma to 23 hours of abuse. She was slapped and kicked, sexually harassed, deprived of food, drink and sleep, and handcuffed to an outside basketball frame in the cold winter air, with the aim of forcing her to admit to engaging in prostitution. Having signed a confession under duress, Ma was released at 7 p.m. the following evening. The Jingyang County Police Department then issued a document imposing an administrative punishment fine on Ma Dandan for involvement in prostitution and sentencing her to 15 days' administrative detention. Ma eventually appealed that decision, demanding an apology from the policing authorities, restoration of her reputation and reparation of five million yuan for psychological distress, on the grounds that she was a virgin. ${ }^{1}$

This research was made possible by funding from the Australian Research Council.

"Chunü piaochang an: peichang yu nanti faguan beigao tongqing Ma Dandan" ("Virgin

Female Whoremonger Case" Compensation Problem: Judge and Defendant Also Sympathize With Ma Dandan), Beijing qingnian bao (hereafter Beijing Youth Daily), 24 July 2001; Qiang Fang, "The Case of the Virgin Prostitute: Chinese Media and Legal Reform", Stanford Journal of East Asian Affairs, Vol. 2 (2002), pp. 26-40; "Shaanxi liqi 'chunü piaochang an': ershen panjue Ma Dandan buman" (Ma Dandan Is Not Satisfied With the Second Verdict In the Absurd "Virgin Female Whoremonger Case"), Xinhua News Agency, 11 December 2001, http://www.people.com.cn/GB/shehui/20011211/ 624687.html (accessed 25 September 2009); Yu Teng, "Huangtang chunü piaochang an zuori zhongshen xuanban Ma Dandan gaoying liang ji gong'anju" (Absurd Virgin Whoremonger Case Finished Yesterday: Ma Dandan Won Against Two Different Levels of the Public Security Bureau), Huashang bao (hereafter Chinese Business News), 12 December 2001; Yu Teng and Hao Miao, “'Chunü piaochang an' faguan beigao tongqing 
The police handling of "virgin" Ma Dandan became a national scandal on 9 February 2001 when her initial request for an official apology met with no response and she disclosed the details of her case and intended appeal to the biggest local newspaper, the Chinese Business News (Huashang bao 华商报). More than 100 domestic newspapers and 10 television stations, including China Central Television Station, Xinhua News Agency, People's Daily Online, Beijing Youth Daily (Beijing qingnian bao 北京青年报) and Southern Weekend (Nanfang zhoumo 南方周末), covered Ma Dandan's story and subsequent court proceedings. ${ }^{2}$ This involvement highlights the media's expanded role as avenues of citizen redress in present-day China. Since the introduction of anti-corruption measures in the mid 1990s, "China's media have become increasingly critical in their news coverage, exposing alleged wrongdoing, criticizing officials for failure to address injustice, and influencing both the outcome of individual disputes and the interpretation of existing legislation". ${ }^{3}$

Media coverage of what became known as the "virgin female whoremonger case" (chunü piaochang an 处女嫖娼案) focused on three arguments relating to police corruption and abuse of power. First, all citizens, including police officers, are equal before the law, and those who break the law should be punished. Second, citizens who are suspected of committing an offence have the right to be treated in accordance with the law and should be compensated by state authorities when they are not. Finally, the police emphasis on fining prostitution offenders should be altered because it encourages malfeasance in the pursuit of revenue, such as fabricating cases and failure to follow due legal process. ${ }^{4}$

Ma Dandan" ("Virgin Female Whoremonger Case": Judge and Defending Lawyer Sympathize With Ma Dandan), Chinese Business News, 24 July 2001; and "Xingxun bigong jingrang chunü cheng piaoke" (Forced Confession Turns a Virgin Into a Prostitute Client) (2001) Nanfang dushi bao (hereafter Southern Metropolitan News), 10 February 2001.

2 Qiang Fang, "The Case of the Virgin Prostitute", p. 27; Hao Miao, Yu Teng and Zhou Qin, "Chunü piaochang an' ershen: Ma Dandan tongku tandao" (Second Trial of the "Virgin Female Whoremonger Case": Ma Dandan Cries and Collapses in Court), Sina.com.cn, 19 July 2001, http://news.sina.com.cn/s/2001-07-19/306110.html (accessed 25 September 2009); Yu Teng and Hao Miao, “'Chunü piaochang an' faguan beigao tongqing Ma Dandan".

3 Benjamin Liebman, "Watchdog or Demagogue? The Media in the Chinese Legal System”, Columbia Law Review, Vol. 105, No. 1 (2005), p. 6.

4 Qiang Fang, "The Case of the Virgin Prostitute", p. 29; Sheng Xueyou, "Guniang canzao feiren zhemo: Hebei ye bao "chunü piaochang an"' (Girl Suffers Inhuman Torment: Another "Virgin Female Whoremonger Case" in Hebei), Sohu.com (2002), http://news.sohu.com/14/86/news204678614.shtml (accessed 11 January 2006); Yan Yang "San wen "chunü maiyin an" (Three Questions About "Virgin Prostitute Cases"), Qianlong xinwang, 6 June 2003, http://health.sohu.com/07/67/harticle17366707.shtml (accessed 2 June 2008); Yu Yang, “Jingcha wei qian buxi niezao yuan'an Henan you bao 'chunü maiyin' an" (Police Go Out of Their Way to Unjustly Accuse People to Make Money: 
The media controversy surrounding these cases raises questions about China's proclaimed reform-era adoption of a "rule of law". Rule of law refers to a system in which the law is able to impose impartial, regularized and commonly understood restraints on how governing authorities exercise power, as encapsulated in notions of the supremacy of the law and equality of all before the law. In contrast, "rule by law" refers to an instrumental conception of the law as an essentially coercive tool "to be used as the state sees fit". ${ }^{5}$ China's prostitution controls, especially police-led campaigns against prostitution, are criticized by both domestic and international commentators for highlighting the Party-state's instrumental view of law as a "weapon" that not only empowers police enforcement activities but also demonstrates, through the associated problems of corruption and malfeasance, that police officials, unlike ordinary citizens, are "above and beyond the law".

An analysis of the virgin prostitute cases and the changing body of prostitution law suggests that, in introducing more lenient and regularized prostitution controls and stricter controls over the exercise of police powers, China is at least sensitive to such arguments. Recent legal changes have placed new limits on the potential for police corruption and malfeasance, and offer better protection of the citizen rights of those apprehended as minor prostitution offenders.

\section{China's Prostitution Laws 1979-2006}

Prostitution is a relatively new object of legal regulation in the PRC, even though the Chinese Communist Party (CCP) is renowned for its longstanding condemnation of the prostitution industry. In keeping with Marxist theory, the early CCP viewed the institution of prostitution as an expression of the exploited and denigrated position of women under feudal-capitalist patriarchy and therefore as incompatible with the desired goals of building socialism and establishing more equitable socio-sexual relations. Following its assumption of national political power in 1949, the CCP embarked upon a series of campaigns that purportedly eradicated prostitution from the mainland by the late $1950 \mathrm{~s} .{ }^{8}$ The extraordinary nature of this feat, irrespective of its actual validity, meant that the eradication of prostitution was (and is) vaunted as one of the major accomplishments of the new regime. Indeed, a recent PRC government white paper still describes it as an "earth-shaking historic change in

Henan Has Another Virgin Prostitute Case), Zhongguo qingnian bao (hereafter China Youth Daily), 16 December 2002.

5 Randall Peerenboom, China's Long March Toward Rule of Law (Cambridge; New York: Cambridge University Press, 2002), pp. 2 and 8.

6 For example, see "China: Extensive use of Torture-From Police to Tax Collectors to Birth Control Officials" (Amnesty International, 2001).

7 Friedrich Engels, The Origin of the Family, Private Property and the State (New York: International Publishers, 1972 [1884]).

8 Elaine Jeffreys, China, Sex and Prostitution (London; New York: RoutledgeCurzon, 2004), p. 96. 
the social status and condition of women". ${ }^{9}$ The extraordinary nature of this purported statement also meant that prostitution effectively "disappeared" as an object of governmental concern in "New China" until it reemerged coincident with the nation's post-1978 shift from a planned to a market-based economy.

The perception at the beginning of the reform period that prostitution was a "non-issue" is highlighted by the limited attention paid to it in the PRC's first Criminal Law of $1979 .{ }^{10}$ Only two Articles in that Law dealt directly with the subject of prostitution. Article 140 stipulated that whoever forced women into prostitution should be sentenced to not less than three years' and not more than 10 years' fixed-term imprisonment. Article 169 stated that whoever lured women into prostitution or sheltered them in prostitution with the intention of profiting from this should be sentenced to not more than five years' imprisonment, criminal detention or administrative control, with additional provisions for more serious offences. The PRC's first penal code therefore banned all third-party attempts to profit from the prostitution of others, but it made no explicit reference to the activities of first-party participants in the prostitution transaction-sex workers and their clients. The 1979 response to prostitution was thus abolitionist but not prohibitionist. ${ }^{11}$

The Chinese police handled the visible resurgence of prostitution in the mid1980s primarily under the system of administrative sanctions rather than the criminal code. During the Maoist period (1949-76), the formal legal system fell into disrepute, as a tool of class-based oppression, and was replaced by a system of administrative and Party disciplinary sanctions. ${ }^{12}$ This system was used to police the activities of those who were deemed to have committed social offences or political "errors", but whose criminal liability was not deemed sufficient to bring them before the courts. Accordingly, the legal control of "women who sold sex" (maiyin funü 卖淫妇女) and "men who bought the services of illicit prostitutes" (piaosu anchang 嫖宿暗娼) was based on provincial rulings and localized policing initiatives, until the introduction in January 1987 of the "Regulations of the People's Republic of China on Administrative Penalties for Public Security" (Zhonghua Renmin Gongheguo zhi'an guanli chufa tiaoli 中华人民共和国治安管理 处罚条例, hereafter the 1986 Regulations). ${ }^{13}$ Article 30 states that it is forbidden

9 Information Office of the State Council of the People's Republic of China, Chapter 1: "Historic Liberation of Chinese Women", in The Situation of Chinese Women (1994), http://www.china.org.cn/e-white/chinesewoman/indes.htm (accessed 18 September 2009).

Criminal Law of the People's Republic of China, adopted at the Second Session of the Fifth National People's Congress on 1 July 1979, promulgated by Order No. 5 of the Chairman of the Standing Committee of the National People's Congress on 6 July 1979, and effective as of 1 January 1980, http://www.novexcn.com/criminal law.html (accessed 19 May 2009).

11 Elaine Jeffreys, China, Sex and Prostitution, pp. 91-92, 106-07.

12 John B. Starr, Understanding China: A Guide to China's Economy, History and Political Structure (London: Profile Books, 2001), pp. 204-19.

13 Regulations of the People's Republic of China on Administrative Penalties for Public Security, adopted at the Seventeenth Meeting of the Standing Committee of the Sixth 
to sell sex and to have illicit relations with a prostitute, to introduce others into prostitution, and to provide accommodation for the purposes of prostitutional sex. Suspected offenders could be held in custody for a period of 15 days while investigating officials determined the particulars of the case, and could then be given a warning and ordered to make a statement of repentance or, in accordance with other administrative regulations, they could be detained for rehabilitative education and/or reform through labor for a period of between six months to two years, and fined up to 5,000 yuan. This meant that the vast majority of prostitutionrelated cases - the processes of investigating, determining guilt and suitably penalizing the activities of sellers and buyers of sex-were (and are) handled by the Chinese police, with only serious cases, such as those relating to organized and forced prostitution, being managed through the courts and criminal justice system.

Although new legislation was introduced in the 1990s, until 1 March 2006 policing authorities retained the power to fine and detain first-party participants in the prostitution transaction on the general basis of the 1986 Regulations. The prostitution transaction became a distinct object of legal classification in September 1991 with the promulgation of the "Decision on Strictly Forbidding the Selling and Buying of Sex" (quanguo renmin daibiao dagong changwu weiyuanhui guanyu yanjin maiyin piaochang de jueding 全国人民代表大会常务委员会关于严禁卖淫嫖娼的决定， hereafter the 1991 Decision), which was issued in conjunction with the "Decision on Severely Punishing Criminals Who Abduct and Traffic in or Kidnap Women and Children" (guanyu yancheng guaimai, bangjia funü, ertong de fanzui fenzi de jueding 关于严惩拐卖、绑架妇女、儿童的犯罪分子的决定). ${ }^{14}$ The 1991 Decision aimed to provide a legal basis for police-led crackdowns against the rapid spread of prostitution throughout China's burgeoning hospitality and service industry, chiefly by supplementing the limited reference to prostitution in the penal code. The 1991 Decision extended the provisions contained in the 1979 Criminal Law by introducing a system of sanctions against any person who took advantage of their work-based location in the hospitality and service industry to organize, force, facilitate or induce other persons to participate in prostitution. However, it kept the prostitution transaction under the purview of the system of administrative and Party disciplinary sanctions by stipulating that sellers and buyers of sex should be handled according to Article 30 of the 1986 Regulations.

National People's Congress on 5 September 1986 and promulgated by Order Number 43 of the President of the People's Republic of China on 5 September 1986, http://www.china.org.cn/english/government/207301.htm (accessed 21 August 2009); (in Chinese) http://www.jincao.com/fa/law25.01.htm (accessed 21 August 2009).

14 Quanguo renda changweihui, xingfashi bianzhu, fazhi gongzuo weiyuanhui (Criminal Law Office and the Legal Council of the Standing Committee of the National People's Congress), Guanyu maiyin piaochang de jueding he guanyu yancheng guaimai bangjiafunü, ertong de fanzui de jueding shiyi (An Explanation of the Decision on Strictly Forbidding the Selling and Buying of Sex and the Decision on the Severe Punishment of Criminals Who Abduct and Traffic In or Kidnap Women and Children) (Beijing: Zhongguo Jiancha Chubanshe, 1991). 
The provisions contained in the 1991 Decision were eventually codified in the PRC's revised Criminal Law of 1997 and the 1999 "Regulations Concerning the Management of Public Places of Entertainment" (yule changsuo guanli tiaoli 娱乐 场所管理条例, hereafter the Entertainment Regulations). ${ }^{15}$ As with the 1991 Decision, Article 361 of the revised penal code aims to restrict the conditions that contribute to the formation of a prostitution industry by introducing a system of controls over recreational enterprises and the people who own, manage, or work within them. Article 362 extends this concern by stating that hospitality and service industry personnel who leak information about prospective police investigations into the existence of prostitution activities in their work unit will be convicted for obstructing the course of justice. Once again, the revised penal code did not criminalize the behaviors of first-party participants in the voluntary prostitution transaction, with the exception of clauses relating to sex with minors and the premeditated spread of sexually transmissible infections ${ }^{16}$ First-party engagement in the voluntary prostitution transaction remained an unlawful, not criminal, act, which the Chinese police handled according to administrative sanctions.

The 1999 Entertainment Regulations reiterated the provisions outlined in the 1997 penal code by forbidding all forms of commercial sexual activities in recreational enterprises, including the provision of "accompaniment" or "hostessstyle" services, which had become a known front for prostitution activities by the mid-1990s. ${ }^{17}$ To support this ban, the Entertainment Regulations aimed to restrict the available pool and turn-over of labor within the hospitality and service industry by reinforcing the long-standing stipulation in China that all personnel must possess a residency permit, or a temporary work and residency permit, and hence be "known" to the local police. The Entertainment Regulations also aimed to control the existence of governmental corruption by stipulating that members of China's public security forces and their families are not permitted to run recreational enterprises. However, they gave police above county level the authority to vet, license and investigate recreational enterprises to ensure that they complied with Chinese law.

China's proliferating body of prostitution-related legislation provided a necessary yet problematic legal basis for the implementation of police-led campaigns against the burgeoning prostitution industry throughout the 1990s.

15 Criminal Law of the People's Republic of China, Adopted at the Second Session of the Fifth National People's Congress on 1 July 1979, Revised at the Fifth Session of the Eighth National People's Congress on 14 March 1997, http://www.cecc.gov/pages/ newLaws/criminalLawENG.php (accessed 11 May 2009; Zhonghua Renmin Gongheguo guowuyuan (State Council of the PRC), Yule changsuo guanli tiaoli (hereafter, Regulations Concerning the Management of Public Places of Entertainment) (Beijing: Wenhua Chubanshe, 1999).

16 Article 360, All-China Women's Federation, "Criminal Law of the People's Republic of China (Excerpts)", http://www.women.org.cn/english/english/laws/07.htm (accessed 14 September 2009).

17 Regulations Concerning the Management of Public Places of Entertainment, 1999. 
Police-led campaigns against prostitution had been implemented in China since the early 1980s, usually as part of broader campaigns to crack down on the newfound "social problems" of the reform era, including growing rates and types of crime, as well as phenomena deemed in need of "special attention", such as prostitution, trafficking in women, pornography and drugs. ${ }^{18}$ However, such campaigns have attracted domestic and international criticism for encouraging police corruption and malfeasance.

\section{Police-led Crackdowns on Prostitution}

The first and most notorious of China's reform-era policing campaigns - the 1983 "strike hard" (yanda 严打) campaign against criminal activity_was launched following a July meeting between Deng Xiaoping and leading members of the Ministry of Public Security. This meeting concluded that resolving the nation's escalating crime problem required mobilizing "the masses", but the nature of that mobilization had to differ from that of the political movements of the Maoist era. ${ }^{19}$ The campaign process, previously a Maoist tool of continuing class struggle, was subsequently resurrected as a pragmatic tool of policing. Instead of launching wave after wave of mass mobilization campaigns against political deviation, class enemies and so forth, policing authorities began to target certain proscribed activities, and types of persons, places and behaviors, for a limited period of time. ${ }^{20}$ This campaign-style policing operates in China to this day, although its form and content has evolved in response to the emergence of new problems in public order and the promulgation of new laws.

Campaign-style policing initially found favor among China's public security forces because it enabled them to respond to government and public demands that they do something about the deteriorating public order situation by directing their limited resources at specified targets and circumscribed goals. For example, in November 1989 the PRC launched a major policing campaign against the "Six Evils" (liu hai 六害)—prostitution, gambling, the manufacturing and sale of pornography, the manufacturing and sale of drugs, kidnapping and selling women, and using feudal superstition to deceive and harm people. ${ }^{21}$ This campaign helped to bolster flagging public confidence in the CCP-led regime following the brutal suppression of student

18 Elaine Jeffreys, China, Sex and Prostitution, p. 155.

19 Deng Xiaoping, "Crack Down On Crime”, Selected Works of Deng Xiaoping, Vol. 3 (Beijing: Foreign Languages Press, 1994), pp. 44-45.

20 Sarah Biddulph, Legal Reform and Administrative Detention Powers in China (Cambridge: Cambridge University Press, 2007), pp. 152-76; Michael Dutton and Lee Tianfu, "Missing the Target? Policing Strategies in the Period of Economic Reform", Crime and Delinquency, Vol. 39, No. 3 (1993), pp. 316-36; Elaine Jeffreys, China, Sex and Prostitution, pp. 150-76; Murray Scot Tanner, "Campaign-style Policing in China and Its Critics", in Børge Bakken (ed.) Crime, Punishment, and Policing in China (Lanham: Rowman and Littlefield, 2005), p. 171.

21 Sarah Biddulph, Legal Reform, pp. 136-37. 
and worker protesters in Tiananmen Square in June of that year, both by responding to student complaints of moral turpitude among political leaders and by attacking some of the "new-found problems" of the reform era. ${ }^{22}$

However, the continuing implementation of police-led crackdowns on crime and illegality has attracted criticism from international and domestic commentators for undermining China's proclaimed reform-era adoption of a rule of law. As human rights activists based in the West argue, campaign-style policing undermines efforts to improve standards of policing professionalism and accountability, because it relies on the flexibility of the administrative system rather than on the procedural rules that govern the operation of the penal code and criminal justice system. ${ }^{23}$ Prior to the introduction of the revised Criminal Law of the PRC in 1997, the launching of a major campaign was often accompanied by the introduction of harsher legislation designed to facilitate easier arrest, detention and sentencing, including the extensive use of capital punishment. At the same time, huge numbers of people were detained on the basis of the former system of administrative sanctions and held for arbitrary periods of time in centers which frequently had appalling conditions. In the mid-1990s, Chinese policing scholars similarly expressed concern that crackdowns against prostitution per se were harming the PRC's international reputation because regulations pertaining to the types and periods of detention for participants in the prostitution transaction were imprecise, thus encouraging arbitrary sentencing practices, and because centers for the administrative rehabilitation of first-party participants in the prostitution transaction were understaffed, underfunded and overcrowded. ${ }^{24}$

A now-common domestic and international criticism of police-led crackdowns against prostitution is that they are punitive and ineffective. As many commentators argue, both frequency rates and types of prostitution have increased and spread throughout the PRC, despite the continuing implementation of policing campaigns and an escalating series of arrests. Venues which facilitate or provide sexual services close during the campaign-cycle, only to re-open once it is over; the women who work in such venues simply go home to visit their families, move to more secure venues, or reinvent themselves as "legitimate workers" such as waitresses. ${ }^{25}$ Local police often express a lack of enthusiasm for

22 Sarah Biddulph, Legal Reform, p. 136; Michael Dutton and Lee Tianfu, "Missing the Target?", p. 323.

23 Human Rights in China, "Not Welcome at the Party: Behind the 'Clean-up' of China's Cities-A Report on Administrative Detention Under 'Custody and Repatriation"”, HRIC Arbitrary Detention Series, No. 2, September 1999, http://www.hrichina.org/ public/PDFs/Reports/C-R 99.pdf (accessed 25 September 2009).

24 Wang Dazhong, "Guanyu maiyin piaochang renyuan de laojiao yu qiangzhi jizhong jiaoyu de wenti" (Some Problems Concerning the Sending of Prostitution Offenders to Education Through Labor and Compelling Them to Undergo Joint Detention and Education), Fanzui yu gaizao (Crime and Reform), No. 6 (1995), p. 57.

25 Suiming Pan, "Interview: Rough Trade, Rough Justice", China Development Brief, 1 June 2002. http://www.eteem.net/node/166.htm”, last accessed 1 December 2009; Heqing Zhang, 
crackdowns on prostitution and complain of fatigue resulting from the recurring nature of these campaigns. ${ }^{26}$ Moreover, the continuing lack of success of policeled crackdowns against prostitution simply encourages harsher responses.

Another criticism of police-led crackdowns on prostitution is that they are motivated at the local level by income creation through extortion and the issuing of fines, rather than by concerns about law enforcement or abolishing the prostitution industry. ${ }^{27}$ Some commentators contend that prostitution-related police corruption is entrenched, with local police profiteering from the running of recreational enterprises that provide sexual services or turning a blind eye to the existence of prostitution activities during non-campaign periods in return for financial "kickbacks". ${ }^{28} \mathrm{~A}$ more common and verifiable complaint is that campaign-style policing encourages arbitrary policing practices and revenue-raising tactics. These criticisms are most forcibly expressed by human rights activists and organizations located outside China. In the words of a posting by one anonymous netizen on a Taiwanese website: "Each brick in every newly erected Public Security Bureau building is made up of the receipts from fines and other dirty doings". ${ }^{29}$ More dramatically, a 2001 report by Amnesty International claims:

Many women have been tortured, including being raped and sexually abused by police who accuse them of prostitution. Police have the power to issue an instant fine on suspected prostitutes and send them and their alleged clients for up to two years' detention for "custody and education". Police choose to detain and torture women in order to extract lists of alleged clients to blackmail. Many alleged prostitutes and clients have died under torture. ${ }^{30}$

As these criticisms suggest, the system of administrative sanctions created serious problems throughout the 1990 s and early 2000 s, even though this system was based in theory on a principle of leniency.

"Female Sex Sellers and Public Policy in the People's Republic of China", in Elaine Jeffreys (ed.) Sex and Sexuality in China (London; New York: Routledge, 2006), p. 146.

26 Sarah Biddulph, "The Production of Legal Norms: A Case Study of Administrative Detention in China", UCLA Pacific Basin Law Journal, Vol. 20, No. 2 (2004), pp. 217-77; Murray Scot Tanner, "Campaign-style Policing", p. 179.

27 Suiming Pan, "Interview"; Heqing Zhang, "Female Sex Sellers", p. 146. See also Hualing Fu and D. W. Choy, "Administrative Detention of Prostitutes: The Legal Aspects", in Joseph Tucker and Dudley L. Poston (eds), Gender Policy and HIV in China: Catalyzing Policy Change (The Netherlands: Springer, 2009), pp. 194-95.

28 "Shanghai's Dark Side", Asia, Inc., 1997, http://orgcrime.tripod.com/darkside.htm (accessed 14 September 2009). See also Suiming Pan, "Interview", who suggests that there is neither evidence nor need for such an entrenched form of corruption, as revenue-raising through the fining of minor prostitution offenders is both "legal" and more practical.

29 "Lun maiyin buneng hefahua de zhenzheng yuanyin" (The Real Reason Why Prostitution Cannot Be Legalized), Taihai wang (Taiwan Net), 24 February 2004, http://bbs.taihainet.com/showtopic-185.html (accessed 10 May 2009).

30 "China: Extensive Use of Torture" (Amnesty International). 
The continuing implementation of campaigns against crime and illegality also put pressure upon the entire administrative system, as the Chinese police used their authority not only to detain a wide range of offenders but also to meet targets or quotas by side-stepping the more rigorous evidentiary and sentencing procedures required by the criminal justice system. Administrative reform centers subsequently became overcrowded and increasingly costly to run, exacerbating the already poor conditions in them and encouraging the practice of releasing those apprehended as first-party participants in the prostitution transaction with a warning and punishment fine. In turn, the fining of minor prostitution offenders became a way for cashstrapped local police to generate revenue. Although the 1986 Regulations stipulated that all the monies received from administrative punishment fines belonged to the state treasury, and a 1997 ruling prohibited the use of quotas and the substitution of fines for detention, local police were able in practice to retain a significant proportion of the income derived from the issuing of fines. ${ }^{31}$

The tendency for local police to treat the fining of minor prostitution offenders as an income-generating activity became particularly pronounced when a series of campaigns were launched to enforce the 1999 Entertainment Regulations. Following the promulgation of the Entertainment Regulations, the National People's Congress urged the Ministry of Public Security and the Ministry of Culture to crack down on "accompaniment-style services" within China's recreational enterprises, irrespective of the cost to relevant departments and of local government fears concerning the potentially deleterious short-term economic costs of doing so. The response, which highlights continued Party leadership over policing policy and strategy, was a national campaign to reduce drastically the number of recreational enterprises in the PRC. The campaign sought to control the heavy competition between enterprises, which was deemed to encourage prostitution and illegality. In addition, efforts were made to curb the establishment of luxury nightclubs and "private" venues - namely, venues that were not patronized routinely or openly by the public, and which thus may have been profiting from the abuse of public funds, the provision of proscribed activities and protection by local government or police..$^{32}$ During the latter half of 2000 , the Chinese police, in conjunction with numerous other government departments, closed down nearly one million recreational enterprises of various kinds. These included hotels, karaoke/dance venues, saunas, bath-houses, health and fitness centers, hairdressing salons, barber shops, teahouses, video arcades, and Internet cafes; the overwhelming majority were closed for not possessing relevant business licenses and standard fire and safety equipment. ${ }^{33} \mathrm{~A}$ series of follow-up campaigns were implemented throughout various parts of the PRC during 2001 and 2002.

China's virgin prostitute cases emerged in this context, highlighting an alarming degree of police malfeasance through the arbitrary fining of minor prostitution offenders.

31 Sarah Biddulph, "The Production of Legal Norms", p. 239; Hualing Fu and D. W. Choy, "Administrative Detention of Prostitutes", pp. 194-95.

32 Zhiping Zhang, "Does China Need a Red-light District?”, Beijing Review, 12 June 2000, p. 33.

33 "Million Bars Closed", Advertiser (Adelaide), 30 January 2001, p. 22. 
Domestic media coverage of these cases, along with other exposés of serious police misconduct in the early 2000s, generated calls to alter policing powers and procedures. ${ }^{34}$ Specifically, media coverage of these cases generated calls to amend the PRC's prostitution controls in order to curb police abuses of power and allow citizens to claim legal redress for losses incurred and injuries experienced as the result of unlawful acts by state personnel exercising criminal jurisdiction and administrative powers.

\section{Ma Dandan: China's “Original” Virgin Prostitute}

Between February 2001 and July 2004, media coverage of the story of Ma Dandan and at least six other virgin prostitute cases focused public attention on police corruption and abuse of power. Following the exposure of Ma Dandan's story in February 2001, China's media covered another virgin prostitute case in Shandong Province during 2001. In 2002, reporters covered a Hebei Province case, a Jiangsu Province case and two in Henan Province. Journalists also covered a Nanjing City virgin prostitute case in $2004 .^{35}$

34 In 2003, as Sarah Biddulph explains: "Chronic abuse of the power of detention for repatriation and the lack of a legal basis to justify its continuing existence led to calls to abolish the power. These voices were galvanized following publicity over the detention and beating to death of a college graduate, Sun Zhigang", and the presentation of a petition by scholars to the National People's Congress, which is China's highest legislative body, to abolish that power. "On 18 June 2003, the Premier, Wen Jiabao, announced that the power to detain would be abolished and replaced with provisions for the shelter and welfare of vagrants". Sarah Biddulph, Legal Reform, pp. 331-32.

35 "Henan 'chunü maiyin an' xuanpan: si minjing bei pan you qi tuxing" (Judgement Passed On Henan Virgin Prostitute Case: Four Policemen Sentenced to Varying Periods of Imprisonment), Sohu.com, 26 December 2003, http://news.sohu.com/45/72/ news205997245.shtml (accessed 14 July 2008); “Henan you bao 'chunü an': san xunjing shexian feifa jujin shoushen" (Another "Virgin Prostitute Case" Exposed in Henan Province: Three Police Officers Stand Trial For Illegally Taking People Into Custody), Zhongguo xinwen wang, 28 May 2002, http://news.sohu.com/86/24/news201142486.shtml (accessed 11 May 2009); "Henan xin an 'chunü maiyin an' yishen panjue" (First Court Judgement On the New "Virgin Prostitute Case" in Henan Province), China Youth Daily, 10 June 2002; Jiang Hanwei and Zheng Lin, "Jiangsu 'chunü maiyin an': gong'anju cheng chunü ye ke maiyin" (Jiangsu "Virgin Prostitute Case": Public Security Bureau Says Virgins Can Also Sell Sex), China Youth Daily, 13 May 2002; Sheng Xueyou, "Guniang canzao feiren zhemo"; Tai Ping, Zheng Lu and Dong Zhen, “Ma Dandan' shijian Shandong chongyan: bao da xia chunü bei bi zhaoren maiyin" ("Ma Dandan" Incident is Repeated in Shandong: A Virgin Confesses to Being a Prostitute Under Duress), Qilu wan bao (Qilu Evening News), 18 December 2001; "Nanjing bao chunü maiyin an, xuexiao buting jieshi kaichu shean daxuesheng" (Virgin Prostitute Case Exposed in Nanjing; University Ignored Explanation and Expelled Student), Xiandai kuai bao (The Modern Bulletin), 17 July 2004; 'Nanjing jing bao 'chunü maiyin an' wugu daxuesheng bei xuexiao kaichu" (Nanjing "Virgin Prostitute Case" Exposé: University Expels an Innocent Student), Sohu.com, July 2004, http://news.sohu.com/20040722/

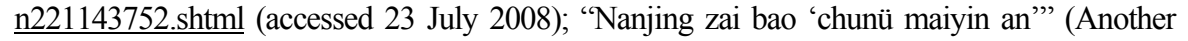
"Virgin Prostitute Case" Exposed in Nanjing), Shanxi wan bao (Shanxi Evening News), 24 July 2004; Yu Yang, "Jingcha wei qian". 
Although the details of China's virgin prostitute cases vary, they share the following features. A young woman who works in the hospitality and service industry, typically in small venues associated with the provision of commercial sexual services, is detained by police officers for questioning about alleged involvement in prostitution, often without regard for correct legal procedure. She is then physically and/or verbally abused until she confesses to engaging in prostitution and, in some instances, until she provides the apprehending officers with a "client list". A client list consists of the names of men who have allegedly bought sexual services from someone categorized as a seller of sex and whom the Chinese police can investigate and potentially punish, based on that testimony. The young woman is then given an administrative punishment notice which contains details of a fine and possibly a period of administrative detention. Following her release, the young woman appeals this decision and demands compensation and restoration of reputation on the grounds that medical certification proves that she is a virgin. The majority of cases conclude with the original administrative decision being overturned, some payment of compensation, and the sentencing of police officers to varying periods of imprisonment, usually suspended for several years, on criminal charges such as illegally holding people in custody, physical assault or extracting forced confessions through the use of intimidation and torture (xingxun bigong 刑讯逼供).

As the original and most publicized "virgin prostitute case", Ma Dandan's appeals for justice against police malfeasance bear further recounting because they created a precedent for China's media and their readers. On 9 January 2001, Ma Dandan was issued with an administrative punishment notice from the Jingyang County Police Department which stated that she was being fined and sentenced to 15 days detention for first-party involvement in a prostitution transaction. However, that document incorrectly referred to Ma Dandan as male, was dated 9 February not 9 January, and stated that she was being punished as a whoremonger or prostitute client (piaochang 嫖娼). ${ }^{36}$ Not long after, Ma Dandan requested that the Xianyang City Police Department overturn this notice and issue a formal apology, claiming that she had undertaken a medical examination which proved that she was a virgin. Ma Dandan then underwent a second medical examination at the behest of the Xianyang City Police Department to verify her claim. ${ }^{37}$ Although the results of this examination led to the original administrative decision being rescinded, it did not result in a formal apology. Ma Dandan therefore took her story to a major local newspaper and sought legal aid from students working in the Legal Service Center of China's Northwest University of Politics and Law. ${ }^{38}$

On 13 February 2001, Ma Dandan's legal representative submitted a petition to the Xianyang Qindu District Court charging the Xianyang and Jiangyang Police

\footnotetext{
36 "Shaanxi liqi "chunü piaochang an"”; "Xingxun bigong".

37 Yu Teng, "Kelian Ma Dandan er yan chunü shen" (Poor Ma Dandan Has a Second Virginity Examination), Chinese Business News, 12 February 2001.

38 Yu Teng and Hao Miao, “'Chunü piaochang an”".
} 
Departments with violating her lawful rights and interests as a citizen, and requesting compensation in accordance with the 1994 Law of the People's Republic of China on State Compensation (Zhonghua Renmin Gongheguo guojia peichang fa 中华人民共 和国国家赔偿法). ${ }^{39}$ The petition requested a formal apology from policing authorities and reinstatement of Ma Dandan's reputation, along with compensation of 50,000 yuan for psychological distress, plus the sum of 9,560 yuan for the combined costs of lost salary, medical treatment, transportation and communication. These claims were made on the grounds that the Jingyang and Xianyang Police Departments had variously abused their functions and powers by: 1) unlawfully issuing an administrative punishment notice; 2) unlawfully taking Ma Dandan into custody and holding her in custody; 3) unlawfully interrogating Ma Dandan; 4) unlawfully using police restraint implements while conducting that interrogation; and 5) unlawfully requiring Ma Dandan to undergo a second virginity examination to prove her case for appeal. The petition was resubmitted to the Xianyang Qindu District Court on 14 February, with one major change; Ma Dandan's legal representative altered her request for compensation for psychological distress to a sum of five million yuan. ${ }^{40}$

Ma Dandan's claim for five million yuan compensation for psychological distress flowing from police malfeasance was heard by the Xianyang Qindu District Court on 9 May and rejected on 19 May 2001. ${ }^{41}$ Ma was awarded the sum of 74.66 yuan instead, for two days loss of salary during her period of custody and the medical costs of establishing her virginity. Although Ma Dandan appealed against that decision on 18 July, the Xianyang Middle Court upheld the original verdict on 11 December 2001 and rejected her second claim for five million yuan compensation. The Xianyang Middle Court ordered relevant policing authorities to pay Ma Dandan 74.66 yuan compensation for the original loss of two days salary due to unlawful holding in custody, plus an additional sum of 11,470.44 yuan to cover costs associated with the 180 days that had expired while the case was being heard. These costs included: 9,135 yuan for loss of salary; 669.50 yuan for transportation and accommodation; and 1,671.44 yuan for related medical costs, as Ma had required medical care during the court proceedings due to anxiety and depression. ${ }^{42}$

39 Law of the People's Republic of China on State Compensation, adopted at the Seventh Meeting of the Standing Committee of the Eighth National People's Congress on 12 May 1994, promulgated by Order No. 23 of the President of the People's Republic of China on 12 May 1994, and effective as of 1 January 1995, http://www.cecc.gov/ pages/newLaws/stateCompensationENG.php (accessed 11 July 2008); (in Chinese: http://www.people.com.cn/electric/flfg/d1/940512.html (accessed 20 August 2009).

40 Chen Huanan and Qin Feng, "Shaanxi beizhi 'piaochang' chunü suopei wubai wan" (Shaanxi's Accused Virgin Female "Whoremonger" Demands 5 Million Yuan Compensation), Nanfang ribao (Southern Daily), 16 January 2001.

41 Yu Teng and Hao Miao, “'Chunü piaochang an"”; Yu Teng, “"Jingyang xian huangtang chunü piaochang an' zuo kaiting" (Trial of the Absurd "Jingyang County Virgin Female Whoremonger Case" Started Yesterday), Chinese Business News, 21 March 2001.

42 "Shaanxi liqi 'chunü piaochang an"”; Yu Teng and Hao Miao, “Chunü piaochang an"”; Yu Teng, "Jingyang xian". 
Both courts rejected Ma Dandan's request for compensation for psychological distress as not conforming to the parameters of the PRC's State Compensation Law. This Law only provides for direct losses, including medical fees and loss of earnings during a set period of time for victims. While concurring that relevant police departments had unlawfully detained, interrogated and attempted to impose an administrative punishment on Ma Dandan, both courts also denied her request for a formal apology as not conforming to the parameters of the State Compensation Law. This Law suggests that government departments which violate the lawful rights and interests of Chinese citizens will be liable for compensation and may be required to restore the victim's reputation and extend an apology. However, Ma's reputation had in effect already been restored by the state system, since both courts had decided in her favor, even as they rejected her additional claim for punitive damages.

Journalists cited the courts' verdicts to elicit public sympathy for Ma Dandan as a victim not only of police malfeasance but also of the state's failure to halt those problems and compensate victims adequately. Reporters used her status as a virgin to demonstrate the extent of police corruption, especially in relation to the revenueraising practices associated with the fining of minor prostitution offenders. ${ }^{43}$ Even though Chinese youth increasingly engage in pre-marital sex, female virginity is valued highly in contemporary China, as paradoxically evidenced by the growing popularity of "hymen repair surgery". "Female chastity was also prized in traditional China as demonstrated by numerous accounts of women who were honored for committing suicide following sexual assault, rape or even a suggestion of sexual misconduct, in order to provide public proof of their virtue. ${ }^{45}$ Reporters therefore located Ma Dandan along an historical continuum of virtuous and heroic women to evoke public sympathy for her plight. They further used claims that Ma felt suicidal because her demands for justice were stymied, to argue that the State Compensation Law should allow for punitive damages against state personnel who engage in illegal actions that harm others, and that offending officials should face severe punishments to guarantee a rule of law. ${ }^{46}$

43 Chen Huanan and Qin Feng, "Shaanxi beizhi"; Yu Teng and Hao Miao, "“Chunü piaochang an"”.

44 "Women Opt For Surgery To Restore Virginity", Indo-Asian News Service, 2 April 2005.

45 Elaine Jeffreys, "Over My Dead Body! Media Constructions of Forced Prostitution in the People's Republic of China", Portal: A Journal of Multidisciplinary International Studies, Vol. 3, No. 2 (2006), http://epress.lib.uts.edu.au/ojs/index.php/portal/article/view/126/342 (accessed 14 September 2009); Janet M. Theiss, Disgraceful Matters: The Politics of Chastity in Eighteenth-Century China (Berkeley; Los Angeles; London: University of California Press, 2004), pp. 203-04.

46 "Chinese Experts: Victims of State Abuse Deserve Punitive Awards", China Daily, 23 June 2003; Qiang Fang, "The Case of the Virgin Prostitute", p. 29; Sheng Xueyou, "Guniang canzao feiren zhemo"; "Tuwen: quancheng zhuizong "huangtang chunü piaochang an': wo liangci kanjian Ma Dandan kudao zai di" (Photograph and Report: The "Absurd Virgin Female Whoremonger Case": I Saw Ma Dandan Cry and Collapse On the Floor Twice), Beijing Youth Daily, 25 July 2001; Yu Teng, "Jingyang xian”. 
Journalists buttressed their condemnation of police malfeasance with visual imagery and narrative accounts portraying the continuing psychological torment which Ma Dandan was reportedly experiencing as a result of her terrifying brush with power. These accounts include photographs of Ma Dandan crying and fainting during the first court proceedings where her request for an apology and five million in compensation was denied. ${ }^{47}$ They also include suggestions that Ma and her family wept at the start of the second court hearing and that she was either absent from the final session of that hearing or had not been seen in public for some time, because she was in a more or less catatonic state and suffering from acute depression. ${ }^{48}$ Finally, they include post-court accounts in February 2002 celebrating human compassion, resilience and courage in the face of police malfeasance. These accounts note that Ma had smiled for the first time in 13 months after changing her name and being offered a new job and psychological care by a state-owned company in Shanghai, the staff of which had also established a start-up fund so that Ma could begin her new life in comfort. ${ }^{49}$

\section{China's "Other" Virgin Prostitutes}

Ma Dandan's case clearly established a precedent for China's media, because a report on a second virgin prostitute case published on 18 December 2001, entitled the “Shandong 'Ma Dandan' case", similarly highlighted police malfeasance flowing from the fining of minor prostitution offenders. ${ }^{50}$ In this instance, a 25 -year-old woman, Zhang Dan (alias), was being driven home by her older male employer sometime in mid-November when four police officers stopped the car. The officers took Zhang and her employer to a local police station, where they accused the two of participating in the prostitution transaction and proceeded to slap and intimidate them until they signed a confession. Police officers then imposed an administrative fine of

47 Yu Teng, “Jingyang xian”; Zhou Qin and Yu Teng, “'Chunü piaochang an' ershen muji: Ma Dandan tandao fating" (Eye-witness to the Opening of the Second Court Hearing of the "Female Virgin Whoremonger Case": Ma Dandan Collapses in Court), Jiangnan shibao (hereafter Jiangnan Times), 19 July 2001, p. 3; "Tuwen".

48 Hao Miao, Yu Teng and Zhou Qin, “Chunü piaochang an' ershen”; Yu Teng, "Huangtang chunü piaochang an"; Yu Teng, "Bei wu piaochang yinian zibi jinzhao xinsheng, Ma Dandan xiao le" (Ma Dandan Smiles and Starts a New Life After a Year of Suffering in a Catatonic State Following False Accusations of Whoremongering), Beijing Youth Daily, 6 February 2002.

49 “'Chunü piaochang an' da jieju: Ma Dandan kuaile jiu ye Shanghai” (Great End to the "Virgin Whoremonger" Case: Ma Dandan is Happily Employed in Shanghai), Beijing Youth Daily, 4 February 2002; Yu Teng, "Bei wu piaochang yinian zibi jinzhao xinsheng"; Yu Teng, "'Huangtang chunü piaochang an' zuixin jinzhang: Ma Dandan zuo fei hu shangban" (New Development in the Absurd "Virgin Female Whoremonger Case": Ma Dandan Flew to Shanghai to Start Work Yesterday), Jiangnan Times, 1 March 2002, p. 3.

50 Dong Zhen, "Shandong 'Ma Dandan' anxu: chunü beibi zhaoren maiyin jingzhang tingzhi" (Shandong "Ma Dandan" Case Continues: Police Chief Suspended For Forcing a Virgin to Confess to Engaging in Prostitution), Bandao dushi bao (Bandao Metropolitan News), 23 December 2001; Tai Ping, Zheng Lu and Dong Zhen, “"Ma Dandan' shijian Shandong chongyan". 
5,000 yuan on both Zhang and her employer, as minor prostitution offenders. This incident reportedly damaged Zhang Dan's reputation, resulting in the disapproval of her work colleagues and a break-up with her boyfriend of two years' standing. As with the case of Ma Dandan, Zhang underwent a medical examination to verify that she was a virgin, and brought a case for reinstatement of reputation against relevant policing authorities, resulting in the suspension of a police chief.

Journalists reiterated the virgin prostitute theme by exposing four more cases in 2002 to highlight police malfeasance. First, in early March, Jin Lei, a 22-year-old woman from Jiangsu Province, was apprehended by police officers in a hairdressing salon and taken for questioning about alleged involvement in prostitution. ${ }^{51}$ Jin was later issued with an administrative punishment fine and sentenced to 15 days' administrative detention. A medical examination during her period of detention revealed that she was a virgin, resulting in her father taking the story to the local media. Second, on $17 \mathrm{March}$, while returning to her home from a restaurant, Liu Xiaomei was forced into a car by plainclothes police officers and taken to a local police station. ${ }^{52}$ She was then beaten until she confessed to involvement in prostitution and provided the apprehending officers with a "fake" client list. After undergoing a medical examination to prove her virginity, Liu's family gave an interview to the Luoyang Television Station in Henan Province, which resulted in the sentencing of three police officers for abuse of power, and payment of 35,000 yuan compensation to Liu Xiaomei.

Third, in late August, Wu Xiaoling, a 19-year-old barber-shop worker from Hebei Province, was detained by the police and subjected to 82 hours of torture and abuse until she confessed to involvement in prostitution and provided a client list. ${ }^{53}$ $\mathrm{Wu}$ underwent a medical examination to prove that she was a virgin, and brought charges against the apprehending officers for illegally holding her in custody on false charges and extracting a forced confession - she was slapped, beaten with an electric cattle prod and forced to sit on the ground while handcuffed to a heater. Policing authorities responded with a countersuit claiming that $\mathrm{Wu}$ had laid false charges against them. This suit was dropped following media publicity and further police investigations which showed that Wu's client list was fabricated, and charges of misconduct were laid against the relevant policing authorities once again. Finally, in September 2002, Zhang Cuiying, a 22-year-old worker in the service industry, was unlawfully detained, beaten and sexually harassed by police officers for 40 hours until she confessed to engaging in prostitution and provided a client list. Four police officers later received various terms of imprisonment, suspended for several years, on charges of unlawfully holding Zhang in custody on false charges. ${ }^{54}$

\footnotetext{
51 Jiang Hanwei and Zheng Lin, "Jiangsu 'chunü maiyin an"”.

52 Wan Xingya, "Henan xin an 'chunü maiyin an' yishen panjue" (First Court Decision on Henan Province's New "Virgin Prostitute Case"), China Youth Daily, 10 June 2002.

53 Sheng Xueyou, "Guniang canzao feiren zhemo".

54 "Henan 'chunü maiyin an' xuanpan”; "Paozhi 'chunü maiyin' si minjing bei panxing” (Four Policemen Sentenced For Concocted Virgin Prostitute Case), Southern Metropolitan News, 26 December 2003; Yu Yang, "Jingcha wei qian”.
} 
In 2004, China's media covered a seventh virgin prostitute case in Nanjing City, evoking both the precedent of Ma Dandan and the local example of Jin Lei to underscore the entrenched nature of police malfeasance. ${ }^{55}$ At 4.30 p.m. on 10 January, a young female masseuse, Zhang Haiyan, and her client, Wang Jiangang, were taken into custody by two plainclothes police officers for alleged involvement in a prostitution transaction. In follow-up interviews with media reporters, including representatives from a local television station, Zhang claimed that she was merely providing a back massage when two men rushed into the room, and, without showing any identification, proceeded to shout and hit Zhang and Wang, accused them of engaging in prostitution and took them to a local police station for questioning. After 48 hours in custody, Zhang signed a confession based on Wang's testimony admitting to engaging in prostitution. She was then put in a holding center for seven days until her employer paid an administrative punishment fine of 5,000 yuan on her behalf, a sum that allegedly bankrupted the employer. Upon her release, Zhang underwent a medical examination and applied to the Nanjing Police Department for administrative redress on the ground that she was a virgin and had signed a confession under duress, since she was barely literate, did not understand the legal significance of that document, and had simply wanted to go home. ${ }^{56}$

Zhang Haiyan's petition for an administrative review resulted in the original 5,000 yuan punishment fine being rescinded and compensation of 371 yuan based on a legal technicality, as opposed to acceptance of her claims-Zhang's case did not fall under the jurisdiction of the police station where she had been taken into custody. Zhang appealed to the Nanjing Baixia District People's Court on 8 July, demanding a public apology and restoration of reputation. Her appeal was rejected on the grounds that documentary proof of virginity was not relevant to the legal particulars of the case. This decision led media reporters to conclude that the Court was attempting to cover up police malfeasance, arguing that its ruling defied commonsense if not legal sense. Journalists further concluded that the inequitable nature of China's legal system was demonstrated by the fact that Wang Jiangang had been expelled from university for purchasing sexual services from Zhang Haiyan, even though there was no longer the pretense of a legal case to prove that he had in fact done so. ${ }^{57}$

As the number of virgin prostitute cases mounted, reporters began to focus on the need to alter the PRC's prostitution controls in order to halt the problems of police corruption and abuse of power flowing from the fining of minor prostitution offenders. ${ }^{58}$ In some instances, members of public security forces attempted to defend their professional reputation by claiming that examples of prostitution-related malfeasance usually were perpetrated by temporary and untrained staff and did not offer an accurate

\footnotetext{
55 "Nanjing bao chunü maiyin an"; "Nanjing zai bao 'chunü maiyin an"”.

56 "Nanjing zai bao "chunü maiyin an"”.

57 "Nanjing jing bao 'chunü maiyin an"”.

58 "Paozhi 'chunü maiyin”"; Yu Yang, "Jingcha wei qian”.
} 
portrait of Chinese policing. ${ }^{59}$ In other instances, such as the case of Jin Lei from Jiangsu Province, policing authorities attempted to defend their actions by arguing that virginity should not be conflated with innocence or sexual purity, because virgins could and did provide commercial sexual services in the form of oral sex and hand jobs. ${ }^{60}$ These counter-arguments were accorded little space by journalists keen to demonstrate that members of the public security forces were corrupt. ${ }^{61}$ Viewed in conjunction with a spate of cases relating to police malfeasance and the fining of male prostitute clients, ${ }^{62}$ reporters concluded that China's virgin prostitute cases demonstrated the necessity of altering the nation's prostitution controls, not least by removing the opportunities for police profiteering and misconduct flowing from the unlawful fining of alleged minor prostitution offenders. ${ }^{63}$

\section{Amending China's Prostitution Controls}

In March 2006, the Ministry of Public Security issued a circular ordering a nationwide crackdown on unlawful and criminal activities occurring within recreational enterprises, especially prostitution, gambling and drugs. The circular confirmed the PRC's ban on prostitution, while indicating that the campaign would focus on the target population of abolitionist policies: namely, on those who profit from the prostitution of others and are subject to criminal penalties, rather than on minor prostitution offenders. Apart from targeting organizers of prostitution services, the circular noted that local police chiefs would be held responsible for lax law enforcement if prostitution, drug-abuse and gambling were found to be rampant in their area of jurisdiction. Moreover, any police official caught running recreational enterprises or not stopping their relatives from doing so would face severe punishment. ${ }^{64}$ The 2006 campaign thus twinned a campaign against illegality and prostitution to a campaign against corruption. This meant that the Chinese public security forces were obliged as a professional body simultaneously to police both prostitution businesses and practices and the policing of such phenomena. As this example would suggest, China's prostitution

59 Jiang Hanwei and Zheng Lin, "Jiangsu 'chunü maiyin an'”. See also Sarah Biddulph, Legal Reform, p. 237.

60 Jiang Hanwei and Zheng Lin, "Jiangsu 'chunü maiyin an"”.

${ }^{61}$ "Paozhi 'chunü maiyin"”; Yu Yang, "Jingcha wei qian".

62 Elaine Jeffreys, "Governing Buyers of Sex in the People's Republic of China", Economy and Society, Vol. 35, No. 4 (2006), pp. 571-93; Ouyang Xiaoqing, "Jingfang cheng Hunan mou daxue jiaoshou piaochang shouqu 5,000 yuan cai jiangqi fangzou" (A Whoring Professor From a University in Hunan Is Released After Paying 5,000 Yuan to the Police), Qianlong.com, 24 November 2004, http://news.sina.com.cn/s/ 2004-11-24/ 02195011962.shtml (accessed 15 April 2009).

63 Jiang Hanwei and Zheng Lin, "Jiangsu 'chunü maiyin an"”.

64 "China's Entertainment Venues Checked For Drugs, Prostitutes and Gangsters", People's Daily Online, 16 March 2006, http://english.people.com.cn/200603/16/print20060316 250905.html (accessed 17 July 2008). 
controls offer more than a straightforward illustration of the deleterious effects of implementing punitive central policies. They are the locus for a new and complex field of forces, wherein questions concerning both the conduct of the governed and the conduct of government are negotiated.

Unlike similar campaigns in the 1990s, the order to crack down on organized prostitution within recreational enterprises in 2006 coincided with the promulgation of new laws and regulations that reduced the penalties for minor prostitution offences and limited the opportunities for prostitution-related police corruption and abuse of power. The 2005 Public Security Administrative Punishments Law (Zhonghua Renmin Gongheguo zhi'an guanli chufa fa 中华人民 共和国治安管理处罚法), effective 1 March 2006, clarifies and reduces former penalties for first-party engagement in and third-party facilitation of the (voluntary) prostitution transaction. ${ }^{65}$ Article 66 stipulates that selling and buying sex is punishable by between 10 and 15 days' administrative detention with the possible addition of a fine of up to 5,000 yuan; and, in less serious cases, by a maximum of five days' administrative detention or a fine of not more than 500 yuan. It further stipulates that soliciting in recreational enterprises for the purposes of prostitution is punishable by a maximum of five days' administrative detention or a fine of not more than 500 yuan. Article 67 similarly stipulates that facilitating, accommodating and introducing others into prostitution is punishable by between 10 and 15 days' administrative detention with the possible addition of a fine up to 5,000 yuan; and, in less serious cases, by a maximum of five days' administrative detention or a fine of not more than 500 yuan.

Although these stipulations may seem harsh, in that they allow for the temporary deprivation of personal freedom, they are more lenient and precise than previous rulings governing the policing of prostitution in China. The 1986 Regulations not only empowered the Chinese police to detain those who facilitated and engaged in the consensual prostitution transaction for rehabilitative education for periods of up to six months and even two years, and to fine them a maximum of 5,000 yuan, but also allowed very little scope for appeal. ${ }^{66}$ Their lack of precision also encouraged arbitrary sentencing practices and police profiteering from the fining of first-party participants in the prostitution transaction.

A revised version of the Entertainment Regulations also came into effect on 1 March 2006, with the dual goal of curbing illegal activities in recreational enterprises and reducing the scope for police protectionism and cooperation with known offenders. As with the 1999 Entertainment Regulations, the 2006

65 Quanguo renda changwu weiyuanhui (Standing Committee of the National People's Congress), Zhonghua Renmin Gongheguo zhian guanli chufa fa (Public Security Administrative Punishments Law of the People's Republic of China), 2005, http://news.xinhuanet.com/newscenter/2005-08/28/content 3413618.htm (accessed 20 August 2009).

66 Regulations of the People's Republic of China on Administrative Penalties for Public Security. 
Entertainment Regulations aim to create "healthy" public places of entertainment by prohibiting certain categories of people from running them. Prohibited groups include: 1) members of the Chinese police and their families; 2) anyone with a record of administrative detention for selling and buying sex; 3) anyone with a record of forced rehabilitation for drug abuse; and 4) anyone with a criminal conviction for organizing prostitution; manufacturing, peddling and disseminating pornographic goods; drug dealing; rape, sexually abusing women; gambling; laundering money; and belonging to a criminal gang. ${ }^{67}$

The 2006 Entertainment Regulations further aim to reduce local police corruption and protectionism by making managers of recreational enterprises responsible for the activities occurring within them. Article 14 states that employees and patrons of public entertainment venues must not: peddle narcotics; organize others into prostitution; manufacture or distribute pornography; supply or engage in accompaniment or hostess-style services for profit; gamble; encourage sects and superstitions; or engage in any other illegal activity. Any venue with activities that contravene Article 14 faces closure for between three and six months and confiscation of any money or property deriving from the provision of illegal activities. Serious cases may result in the revoking of the enterprise's operating license and the responsible manager being fined between 10,000 and 20,000 yuan. ${ }^{68}$ Articles 30 and 50 reinforce these provisions by stipulating that recreational enterprises should hang signs in prominent and visible spaces that itemize the regulations banning prostitution, gambling and drugs, and which provide a hotline complaint number to police and other relevant government departments. To minimize the potential for local police corruption and protectionism in this context, Article 31 requires managers of recreational enterprises to set up regular internal checks and to notify police or relevant government departments at county level of any illegal activities that they discover. Likewise, Articles 33-35 stipulate that investigating police must keep clear records of any actions or penalties that they impose on the owners, managers, staff and patrons of a recreational enterprise.

Following the introduction of these new laws and regulations, the Ministry of Public Security released a revised set of regulations enforcing stricter controls over the police handling of administrative cases, including minor prostitution offences. On 29 March 2006, the Ministry of Public Security issued the Regulations on the Procedures for Handling Administrative Cases by Public Security Organs (gong'an jiguan banli xingzheng anjian chengxu guiding 公安机关办理行政案件程序规定,

67 Zhonghua Renmin Gongheguo guowuyuan ling, di 458 hao (State Council of the PRC, Order Number 458), Yule changsuo guanli tiaoli (Regulations Concerning the Management of Public Places of Entertainment), passed on 18 January 2006 and coming into effect on 1 March 2006, http://news.sina.com.cn/c/2006-02-13/ 16299089243.shtml (accessed 29 August 2009).

68 Article 42, Regulations Concerning the Management of Public Places of Entertainment. 
hereafter the 2006 Regulations) ${ }^{69}$ replacing an earlier order of 1 January 2004. The 2006 Regulations impose stricter controls over the police handling of administrative cases by requiring that, before the imposition of an administrative punishment, investigating officials provide an accused party with the "facts, evidence and law upon which the decision is based and give reasons for the decision". ${ }^{70}$ They reiterate existing bans on the use of torture, threats and deception to secure confessions, stipulating that police officers are not permitted to interrogate suspects for more than 12 hours at one time and that suspects should be treated with respect and interrogated by two police officers of the same sex as the suspect. In addition, they prohibit the issuing of on-the-spot fines in prostitution cases and grant suspected offenders the right to a hearing if fined more than 2,000 yuan and the right to refuse to pay a fine if the police decline to give receipts printed and issued by financial departments at the provincial level or above. The latter ruling aims to reduce instances of localized police profiteering from the fining of minor prostitution offenders, by eliminating practices such as using hand-written receipts or offering suspects a lesser fine if they choose not to require a receipt.

The introduction of these new laws and regulations appears to have met with some success, in that media coverage of cases relating to virgin prostitutes and police profiteering from the fabricating of prostitution cases has abated. Viewed negatively, this lack of publicity may signify that media coverage of such cases has reached saturation point and/or that journalists have been urged not to publicize cases of prostitution-related police corruption and malfeasance in order to promote public confidence in the utility of new laws. Although China's media are charged with the task of ensuring that the police are subject to "social supervision" by popularizing knowledge of the law and exposing abuses of police powers, they are also required to improve the credibility of the Party and boost public morale. ${ }^{71}$ This means that coverage of controversial social issues, including policing scandals, varies according to practical and political imperatives.

Viewed from a more charitable perspective, China's governing authorities have made significant efforts to legalize, regularize and strengthen supervision of the exercise of police powers in the wake of media condemnation (and documentation) of prostitution-related police corruption and malfeasance. These efforts clearly do not herald a shift away from an abolitionist approach and towards the decriminalization or informal governmental regulation of prostitution in China. On 26 June 2009, the Ministry of Public Security launched a three-month nationwide campaign against forced prostitution, prostitution involving minors,

69 Zhonghua Renmin Gongheguo gong'anbu ling: di 88 hao (Order 88 of the Ministry of Public Security), "Gong'an jiguan banli xingzheng anjian chengxu guiding" (Regulations on the Procedures for Handling Administrative Cases by Public Security Organs), passed on 29 March 2006 to take effect on 24 August 2006, http://www.mps.gov.cn/n16/n1282/n3493/ n3823/n442421/454166.html (accessed 29 August 2009).

70 Sarah Biddulph, Legal Reform, pp. 269-71.

71 Sarah Biddulph, Legal Reform, p. 278. 
organized prostitution within recreational enterprises, and prostitution-related police protectionism, to coincide with the run-up to the $60^{\text {th }}$ anniversary of the founding of the PRC on 1 October. ${ }^{72}$ Nonetheless, regulations designed to prevent or limit capricious use of police powers against minor prostitution offenders, reduce police profiteering and improve transparency in police reporting represent a broad public commitment to tackle the police corruption highlighted by the media. Moreover, legislation reducing and clarifying administrative punishments for first-party engagement in the voluntary prostitution transaction have placed new limits on the potential for prostitution-related corruption and provide better protection of the citizen rights of those apprehended as minor prostitution offenders.

\section{Addendum: China's "Not a Virgin Prostitute Case"}

Increased citizen awareness of both their capacity to contest police malfeasance and the penalties for prostitution-related offences is paradoxically illustrated by controversy surrounding an alleged "virgin prostitute case" in Kunming during 2009. ${ }^{73}$ The case initially received widespread publicity in southern China as an example of police brutality. Police officers reportedly had used excessive force and injured a young woman and her family members suspected of involvement in prostitution, and had later extorted confessions through torture. Media support of the family's ensuing claim for economic compensation flowing from police malfeasance brought the case to the People's Procuratorate. Subsequent investigations rejected the claim of torture, but verified the use of excessive force, and indicated that responsible police officers had faced legal penalties.

These investigations also alleged that the defendants had deliberately resisted police apprehension and fabricated evidence in order to mislead the media into believing that it was a "virgin prostitute case". Knowing that police officers had followed their eldest daughter home to apprehend her for questioning about involvement in prostitution, the father and mother reportedly encouraged their eldest teenage daughter to switch clothing with a younger, virginal sister. The father and a male friend had then attacked the attending officers, and in the ensuing fracas the apprehending officers used excessive force to subdue their attackers and detained the wrong girl for questioning. Upon their release, the father and his friend underwent a medical examination to demonstrate physical injury and the "wrongfully" apprehended daughter underwent a medical examination to prove her virginity.

72 Xiong Tong, "China Launches Three-month Prostitution Crackdown Ahead of National Day", Xinhua News Agency, 30 June 2009, http://www.gov.cn/english/200906/30/content 1353726.htm (accessed 14 September 2009).

73 For different versions of the case which I summarize below, see "New Developments in the Kunming Prostitution Case", Danwei, 3 July 2009, http://www.danwei.org/law/ insert image hereinsert captio 14.php (accessed 25 September 2009); "New Twist to Sex Scandal", China Daily, 12 June 2009, p. 8; and "The 'Virgin' Schoolgirl Prostitutes of Kunming”, EastSouthWestNorth, June 2009, http://www.zonaeuropa.com/ 20090607 1.htm (accessed 25 September 2009). 
The family then took their story and medical documentation to a local journalist and asked for media publicity to support their intended claim for compensation.

In a concluding statement on this "not a virgin prostitute case", the Yunnan Publicity Department indicated that the father was facing charges of compelling his eldest teenage daughter to engage in prostitution, and criticized the local media for acting irresponsibly and hindering legitimate police investigations. This statement generated accusations on the Internet of state-led "silencing" of the media and the "covering-up" of injustice. Irrespective of which version of events may be true, the controversy surrounding this particular case suggests that individual citizens and policing authorities are now not only using the legal and judicial system to protect their rights and reputations but also competing in the media to sway public opinion in their favor. 